\title{
Ownership, Risk and Performance of Mutual Fund Management Companies
}

\author{
Michael K. Berkowitz \\ University of Toronto, Department of Economics and Rotman School of Management \\ Jiaping Qiu \\ University of Toronto, Department of Economics
}

February 2002

\begin{abstract}
This paper compares the performance of mutual funds managed by publicly-traded management companies with those managed by private management companies. We find that publicly-traded management companies invest in riskier assets and charge higher management fees relative to the funds managed by private management companies. At the same time, however, the risk-adjusted returns of the mutual funds managed by publicly-traded management companies do not appear to outperform those of the mutual funds managed by private management companies. This finding is consistent with both the risk reduction and agency cost arguments that have been made in the literature.
\end{abstract}

Contact: $\quad$ Michael Berkowitz

University of Toronto, Department of Economics and Rotman School of Management 150 St. George Street, Toronto, Ontario M5S 3G7

Telephone: (416) 978-2678; Email: berk@ chass.utoronto.ca

Running Title: Ownership of Management Companies

Key Words: Management Companies; Performance; Ownership 


\section{Introduction}

The mutual fund industry has been one of the fastest growing sectors within the Canadian capital market over the past ten years. As shown in Table 1, the growth of the Canadian mutual fund industry has been remarkable. According to the Investment Funds Institute of Canada, as of June 2000, Canadians invested more than $\$ 400$ billion in mutual funds -- more than ten times the total at the beginning of 1991. A survey in 1999 found that close to $40 \%$ of Canadians now own a mutual fund, an increase of $168 \%$ since $1991 .{ }^{1}$ The mutual fund industry has benefitted from a combination of low interest rates, the increasing age of the population, a growing large deficit in the Canada Pension Plan, the moving of savings from defined-benefit pension plans to defined-contribution plans, and an increasing awareness of mutual fund products over the past decade. ${ }^{2}$

The purpose of these popular investment vehicles to provide professional management and the opportunity for investors to diversify. Each mutual fund within the larger fund complex is overseen by a board of directors which is responsible for carrying out the activities of the fund. The board of directors, in turn, appoints a management company that chooses a portfolio manager which in turn determines the composition of the investment portfolio within the bounds set by the fund's objective. Like other business organizations, there are two major forms of ownership structure of these management companies: partnership and corporation.

An interesting puzzle that exists in the industry is that some management companies choose to be publicly-traded on an exchange while others choose not to be. As of June 2000, there were

\footnotetext{
${ }^{1}$ Investors Group/Gallup Canada Survey 1999 Feature Report. Published by Investors Group Inc.

2 These trends are documented in detail by CIBC Wood Gundy Securities Inc Investment Research (January, 1997). Published by the CIBC Wood Gundy Securities Inc.
} 
approximately 200 companies managing mutual funds in the Canadian market and of those, seven were publicly-traded. ${ }^{3}$ Although the number of publicly-traded management companies is relatively small compared to the number of private management companies, they have been playing an important role in the Canadian mutual fund industry. More than 400 mutual funds were under management of these seven publicly-traded management companies as of June 2000. At the same time, the aggregate net asset value managed by these publicly traded management companies was approximately $\$ 155$ billion which accounted for 40 percent of the total assets held by the Canadian mutual fund industry. ${ }^{4}$

Given the growing popularity of mutual funds and their sheer size within the Canadian capital market, it is important to try to get some insight into how the ownership structure of the management companies affects the performance of the mutual funds they manage. ${ }^{5}$ Publicly-traded management companies are characterized by the separation of the ownership and management roles similar to other corporate entities. The question of how diffusion of ownership affects the performance of companies has attracted a great deal of attention in the financial economics literature. Jensen and Meckling (1976) suggested that the managers' incentive to maximize shareholder value increases with

\footnotetext{
${ }^{3}$ They are AGF Management Ltd., C.I. Fund Management Inc., Dundee Bancorp Inc., Investors Group Corp., Mackenzie Financial Corp., Sceptre Investment Counsel Ltd., and Trimark Financial Corp. In August 1998, C.I. Fund Management Inc. acquired all the shares of the BPI financial Corp. BPI financial Corp was also a publicly-traded management company from August 1994 to August 1998.

${ }^{4}$ Financial Post Canadian Mutual Fund Data Base.

${ }^{5}$ Most Canadian mutual funds studies have focused on the performance of individual funds. For example, Grant (1976) found the Canadian mutual funds are conservatively managed and not well diversified. Dhingra (1978) found the ex-post systematic risk levels of mutual funds are consistent with their stated investment objectives. Calvert and Lefoll (1981) concluded that Canadian funds perform no better than the market after risk adjustment. Berkowitz and Kotowitz (1993) looked at the incentives and efficiency in the market for management services and found that the asset-based scheme compensation provides a strong incentive for managers to maximize risk-adjusted fund returns.
} 
their level of ownership. The greater the concentration of ownership, the better is the performance of the firm. Demsetz (1983), however, argued that the shareholder, who decides to dilute the ownership structure, must already be aware of the consequences of the moral hazard problem of the managers. The cost of loosening control over the managers should be offset by other advantages of diluted ownership, such as the lower capital acquisition cost. Therefore, we should not expect to see any relationship between the performance of the firm and the concentration of ownership. In a later paper, Demsetz and Lehn (1985) provided empirical evidence supporting the absence of any systematic relationship between ownership concentration and performance (measured by accounting profit). A few years later, Morck et al (1988) found a significant relationship between firm performance (measured by Tobins Q) and ownership concentration. The authors showed that the performance of the firm increased and then decreased with concentration of ownership. McConnel and Servaes (1990) also found the inverted U-shape relation between performance and ownership of the firm, which is consistent with Morck et al's finding.

Cole and Mehran (1998) examined the performance of a sample of 94 thrift institutions before and after the expiration of an ownership-structure restriction. The authors found that firms performed much better after the restriction expired and better performance was associated with greater ownership concentration. In a recent paper, Himmelberg et al (1999) showed that ownership and performance of the firm are both endogenously determined by some partly observed exogenous variables. After controlling for these exogenous variables (firm characteristics and firm fixed effects), they were unable to conclude that ownership affects the performance of the firm.

The primary goal of this paper is to examine if the ownership of mutual fund management companies affects their performance. This is an important question since if indeed ownership and 
performance are related, investors should take this information into account when they decide in which mutual funds to invest. The link between the performance of mutual funds and the ownership of the management company is through the relationship between historical fund performance and the demand for funds by investors. This relationship has been examined by many authors in the literature and found to be quite strong, irrespective of the performance measure used. ${ }^{6}$ As the performance of the mutual fund increases, investors increase their holdings of the fund causing the net asset value (NAV) of the fund to increase. Since the management company receives a fixed percentage of the $\mathrm{NAV}$, improved performance enhances the flow of fees into the management company which, after expenses, accrues to the owners of the management company. To the best of our knowledge, the relationship between ownership and performance has not been examined for mutual fund management companies. The delegation of decision-making responsibility and the associated agency costs within the mutual fund complex are similar to those within the corporate structure typically studied in the literature. The major advantage of choosing mutual fund management companies when examining the ownership/performance relationship is that it allows us to control for the intra-industry heterogeneity across firms since the technology of the mutual fund management companies is quite homogenous across firms and only requires human capital. The restrictive regulations governing the mutual fund industry also dramatically reduces the companies' idiosyncratic characteristics.

Once the relationship between ownership and performance is established, we then examine how the ownership of mutual fund management companies affects their performance. Diffusion of ownership can affect performance in a number of ways. First, as Jensen and Meckling (1976) pointed

${ }^{6}$ See Berkowitz \& Kotowitz (1993, 2000), Gruber (1996), Sirri \& Tufano (1998), Chevalier \& Ellison (1997), and Del Guercio \& Tkac (2000), among others. 
out, managers of more diffusely held companies are expected to increase their excess perquisite consumption and thus increase the cost of production. A second effect of diffuse public ownership involves the risk-taking incentives of managers. Due to the difficulty of observing the expenditures of managers and the risk of the assets, previous researchers have not been able to differentiate between these two effects. The mutual fund management company provides us a rare opportunity to clarify this issue. For these firms, the link between ownership and manager expenditures can be directly observed through the administrative fees of the mutual funds. If publicly-traded management companies have greater excess perquisite consumption than private management companies, then the difference between the expense ratio and management fee, which includes the administrative fees, will reflect this phenomenon.

Further, unlike most other firms, the risk of the assets held by management companies can be easily measured. Because the assets of the management company consist of the mutual funds they manage, the risk associated with an investment in mutual funds can be calculated from the risk associated with their net asset value returns. There are two competitive arguments in the literature on how the concentration of ownership affects the manager's risk taking behavior. The first argument, by Galai and Masulis (1976), is based on option price theory. The idea is that the greater is the concentration of ownership within firms, the greater is the incentive for the managers to maximize the shareholders' value. Since equity can be viewed as a call option on the value of the firm with the amount of debt as the strike price, given the debt-to-equity ratio, one way for the manager to increase the shareholder's value is to increase the volatility of the underlying assets. Essentially, increasing the risk of the assets transfers wealth from the creditors to the shareholders. However, this argument is not relevant for mutual fund management companies since the fund companies typically have much 
less debt than other types of companies. Hence, the transfer of wealth effect through increasing the risk of the asset holdings may not provide the same benefit to the management companies' shareholders as would be expected with more debt-oriented firms.

The second argument which is presented by Smith and Stulz (1985) is that the greater the managerial ownership, the more risk averse are the managers and hence they tend to adopt more hedging and other risk-reduction strategies. The reason is that the manager's portfolio might not be well diversified and, therefore, as her ownership share increases, she has an incentive to reduce the riskiness of the firms's assets. In a recent paper, Zhang (1998) also showed that in the presence of a controlling shareholder within a firm, the under-diversified controlling shareholder is more averse to risky projects than would be the atomistic shareholders whose portfolios are more diversified. Using a sample of 302 depository institutions, Chen et al (1998) found that as the concentration of ownership increases, the level of risk taking decreases. ${ }^{7}$ Since neither the risk reduction nor wealth transfer argument precludes the existence of the other effect, the relationship between ownership structure and risk taking behavior will depend on which effect dominates the other. As we note above, the wealth transfer effect might be quite weak in mutual fund industry due to its low debt feature, hence, it would be expected that the risk reduction effect is the dominant force for fund management companies. Consequently, the funds managed by publicly-traded managed management companies might have greater risk than do the funds managed by private management companies

At the same time, however, investing in risky assets increases the risk of the managers' portfolio since her income is based on the performance of the mutual funds she manages. In addition, investing in riskier assets usually requires greater effort on the part of managers. Therefore, publicly-

\footnotetext{
7 In an earlier paper, May (1995) also found evidence supporting the risk reduction argument.
} 
traded management companies must provide higher compensation for the managers due to both the greater risk and greater effort they undertake. Consequently, the publicly-traded management companies may charge a higher management fee than the private management companies. However, if publicly-traded management companies are not able to provide sufficiently higher returns to compensate investors for the higher management fees, this might suggest that fund unit-holders should avoid mutual fund managed by the publicly-traded management companies.

The paper is organized as follows. Section 2 examines the governance structure within the mutual fund complex and compares it to that in the usual corporate entity. Section 3 discusses the data. Section 4 examines the performance of the mutual funds managed by the publicly-traded management companies and compares them with the mutual funds managed by the private management companies. Section 5 examines the factors which account for the difference in their performance while Section 6 is by way of summary and conclusions.

\section{Ownership Structure and Performance}

The governance structure within the mutual fund complex of a publicly-owned management company is quite similar to the structure within the typical corporate entity studied in the literature. Figure 1a describes the mutual fund complex when the management company is publicly-owned. For simplicity, we assume a single mutual fund under management. Within this governance structure, the management company is responsible to its shareholders and delegates decision-making responsibility for the composition of the investment portfolio to either an internal or external portfolio manager. Operating expenses of $\mathrm{C}$ are incurred by the management company for administrative, legal, auditing, etc. activities. The portfolio manager, on the other hand, receives a wage contract, 
$\mathrm{W}$, that is typically performance-based and unobservable. The portfolio manager's security selection decisions are reflected in the net asset value of the mutual fund (NAV), with the management company receiving a fixed percentage of the NAV, referred to as the management expense ratio $(\mathrm{m})$, to recover both fees paid to the portfolio manager and all operating expenses, with the remainder accruing to the unitholders of the fund. As residual owners, the shareholders of the management company receive total fees of $\mathrm{m} \times \mathrm{NAV}$ less the incurred aggregate management expenses of $\mathrm{W}+$ C.

Within this structure, there are two agency relationships associated with the delegation of decision-making responsibility. First is the delegation of the choice of portfolio manager by shareholders to the management company. The other is the delegation of security selection, within the basic objectives of the fund, from the management company to the portfolio manager. For the typical corporation studied in the literature, the governance structure is similar to that of the mutual fund complex. Figure $2 \mathrm{~b}$ shows that shareholders delegate employment decisions to management who in turn delegate responsibility to employees who make decisions which affect the revenue flows (R) into the company. Employees receive wages of $\mathrm{W}_{1}$ which may or may not be performance-based and management receives a wage of $\mathrm{W}_{2}$ which is typically tied to performance. The residual of $\mathrm{R}$ $\mathrm{W}_{1}-\mathrm{W}_{2}$ accrues to the shareholders of the firm. As in the case of the mutual fund complex, there are again multiple layers of agency relationships. In the literature that examines the ownershipperformance question, the agency relationship between management and employees of the firm is assumed to be completely resolved by the contract between these parties. Performance is assumed only to be affected by a single agent - management. At the same time, the vast mutual fund literature examining the performance of mutual funds and the relationship between performance and fees, 
focuses exclusively on the fee received by the management company even though performance is influenced by the portfolio manager. Implicitly, it is assumed that the unobserved contract existing between the management company and the portfolio manager is sufficiently complete so as to obviate any agency costs between these two parties. In keeping with these two literatures upon which this paper is based, we also assume that a complete contract exists between the management company and the portfolio manager.

\section{Data Description}

In order to learn how ownership affects the performance of management companies, we examine the performance of the mutual funds managed by Canadian publicly-traded management companies and compare them with the mutual funds managed by Canadian private management companies. Using Canadian data has the advantage that the business of the publicly-traded management companies is reasonably pure. The majority of their business is mutual fund management and the effect of ownership structure on the performance of the management companies will be fully reflected in the performance of the mutual funds they manage. In contrast, U.S. mutual fund management companies are typically involved in other activities, like insurance, underwriting and brokerage businesses so that the relationship between ownership and fund performance is tainted.

During the sample period, from June 1985 to June 1998, there were eight publicly-traded management companies in Canada. ${ }^{8}$ However, the data for the two smallest publicly-traded management companies, Dundee Bancorp Inc. and Sceptre Investment Counsel Ltd, are incomplete.

\footnotetext{
8 The eight publicly-traded management companies are: AGF Management Ltd., BPI Financial Corp.,CI. Fund Management Inc., Dundee Bancorp Inc., Investors Group Corp., Mackenzie Financial Corp., Sceptre Investment Inc., and Trimark Financial Corp.
} 
Therefore, we restrict our analysis to the six largest publicly-traded management companies. In order to compare the performance of the mutual funds managed by these six largest publicly-traded management companies, we choose a matching sample of the six largest private management companies according to the total assets they managed at the beginning of the sample period (June, 1985). ${ }^{9}$ The methodology used to choose these management companies is as follows. First, size of the management companies is an important factor affecting performance since large companies have the technology and capital to take advantage of opportunities that arrive. Therefore, we choose publicly-traded management companies and private management companies whose average total assets under management are above $\$ 100$ million. Second, because companies with superior performance tend to grow larger, we choose the management companies according to their size at the beginning of the sample period. The relative sizes of the management companies selected in the mutual fund industries were very stable and always among the top 15 largest management companies during the sample period in term of total assets under management.

The basic sample includes 446 mutual funds existing in June 1998 managed by the above 12 management companies. The total assets of these funds account for more than 60 percent of the market share of the Canadian mutual fund industry at that time. The basic data set, derived from the Financial Post Mutual Fund Database, covers the monthly net asset value returns of the mutual funds managed by the above 12 management companies from June 1985 to June 1998. Table 2 reports summary statistics for these management companies.

We restrict the analysis to the Canadian funds investing in Canadian equity securities,

\footnotetext{
${ }^{9}$ The private management companies are: Royal Mutual Funds Inc., Fidelity Investments Canada Limited, TD Asset Management, CIBC Securities Inc., Templeton Management Limited, and AIC Limited.
} 
Canadian balanced funds and Canadian equity funds investing in U.S. securities that are managed by these twelve management companies. These three groups of funds constitute the majority of assets in the mutual funds industry. The characteristics of the three fund groups included in our study are summarize in Table 3 . The average size of each comparable publicly managed and privately managed mutual fund is approximately the same, although the management fees are uniformly higher for the publicly managed funds. To evaluate the performance of the management companies, we use both a single factor model and a three-factor model to measure the risk adjusted return of the mutual funds. The methodology used to develop the mimicking portfolio returns for the factors which are constructed from the Compustat Canadian Database and CFMRC/TSE database can be found in Berkowitz (2000).

\section{Does Ownership Matter?}

\subsection{Model and Methodology}

Based on the Lehmann and Modest (1987) model, we assume the data generating process for each of the $\mathrm{J}$ individual security excess returns is:

$$
R_{t}=B F_{t}+\epsilon_{t}
$$

where $\mathrm{F}_{\mathrm{t}}$ is a $\mathrm{K} \times 1$ vector of returns on the mimicking portfolios for the common risk factors at time $\mathrm{t}$; B is the $\mathrm{J} \times \mathrm{K}$ matrix of factor sensitivities; and $\epsilon_{\mathrm{t}}$ is a $\mathrm{J} \times 1$ vector of error terms with its jth row, $\epsilon_{\mathrm{j}}$, representing the idiosyncratic risk of security $\mathrm{j}$ in period $\mathrm{t}$ with mean zero and finite variance.

If the mutual fund companies form a portfolio, conditioning on the data generating process of the individual securities in (1), the return on the mutual fund portfolio $\mathrm{p}$ is: 


$$
\mathrm{R}_{\mathrm{pt}}=\sum_{\mathrm{j}=1}^{\mathrm{J}} \mathrm{w}_{\mathrm{jt}}\left(\mathrm{R}_{\mathrm{j} t}\right)=\sum_{\mathrm{j}=1}^{\mathrm{J}} \mathrm{w}_{\mathrm{jt}} \mathrm{B}_{\mathrm{j}}^{\prime} \mathrm{F}_{\mathrm{kt}}+\mathrm{w}_{\mathrm{jt}} \epsilon_{\mathrm{jt}}
$$

where $\mathrm{w}_{\mathrm{jt}}$ is the weight of security $\mathrm{j}$ in the portfolio at time $t$, and $\mathrm{B}_{\mathrm{j}}{ }^{\prime}$ is a $1 \times \mathrm{K}$ vector consisting of the jth row of B. We can rewrite (2) in matrix form as:

$$
\mathrm{R}_{\mathrm{pt}}=\boldsymbol{\beta}_{\mathrm{pt}}{ }^{\prime} \mathrm{F}_{\mathrm{kt}}+\epsilon_{\mathrm{pt}}
$$

where

$$
\begin{gathered}
\beta_{p t}=\sum_{j=1}^{J} w_{j t} B_{j}^{\prime}=\beta_{p}^{\prime}+\mu_{t} \\
\epsilon_{p t}=\sum_{j=1}^{J} w_{j t} \epsilon_{j t}
\end{gathered}
$$

The vector $\beta_{\mathrm{p}}{ }^{\prime}$ measures the average sensitivity of the fund to the K common risk factors and $\mu_{\mathrm{t}}$ is time t deviation from $\beta_{\mathrm{p}}{ }^{\prime}$ with mean zero and finite variance. Forming the conditional expectation of $\mathrm{R}_{\mathrm{pt}}$ on $\mathrm{F}_{\mathrm{kt}}$ yields:

$$
\mathrm{E}\left[\mathrm{R}_{\mathrm{pt}} \mid \mathrm{F}_{\mathrm{kt}}\right]=\hat{\mathbf{a}}+\hat{\boldsymbol{\beta}}_{\mathrm{p}}^{\prime} \mathrm{F}_{\mathrm{kt}}
$$

where

$$
\begin{gathered}
\hat{\mathbf{a}}=\epsilon_{\mathrm{p}}-\operatorname{Cov}\left[\mu_{\mathrm{t}} \mathrm{F}_{\mathrm{kt}}, \mathrm{F}_{\mathrm{kt}}\right]^{\prime} \Omega_{\mathrm{k}}^{-1} \mathrm{~F}_{\mathrm{k}}+\mathrm{E}\left[\mu_{\mathrm{t}}^{\prime} \mathrm{F}_{\mathrm{kt}}\right] \\
\hat{\boldsymbol{\beta}}_{\mathrm{p}}=\boldsymbol{\beta}_{\mathrm{p}}+\Omega_{\mathrm{k}}^{-1} \operatorname{Cov}\left[\mu_{\mathrm{t}} \mathrm{F}_{\mathrm{kt}}, \mathrm{F}_{\mathrm{kt}}\right]
\end{gathered}
$$




$$
\begin{gathered}
\Omega_{\mathrm{k}}=\mathrm{E}\left[\left(\mathrm{F}_{\mathrm{kt}}-\mathrm{F}_{\mathrm{k}}\right)\left(\mathrm{F}_{\mathrm{kt}}-\mathrm{F}_{\mathrm{k}}\right)^{\prime}\right] \\
\mathrm{F}_{\mathrm{k}}=\mathrm{E}\left(\mathrm{F}_{\mathrm{kt}}\right) \\
\epsilon_{\mathrm{p}}=\sum_{\mathrm{j}=1}^{\mathrm{J}} \operatorname{Cov}\left[\mathrm{w}_{\mathrm{jt}}, \epsilon_{\mathrm{jt}}\right]
\end{gathered}
$$

If we assume no market timing ability, then $\beta_{\mathrm{pt}}$ will be constant $\left(\mu_{\mathrm{t}}=0\right)$. Superior stock picking ability will be indicated by the regression result since equation (5) will be the same as:

$$
\mathrm{E}\left[\mathrm{R}_{\mathrm{pt}} \mid \mathrm{F}_{\mathrm{kt}}\right]=\epsilon_{\mathrm{p}}+\beta_{\mathrm{p}}^{\prime} \mathrm{F}_{\mathrm{kt}}
$$

where $\epsilon_{\mathrm{p}}$ will be greater than zero if the fund managers have stock selection ability, i.e. $\mathrm{w}_{\mathrm{j}}$ is positively correlated with $\epsilon_{\mathrm{jt}}$. Hence, if we estimate (5) using a standard regression model, the intercept, â, will indicate the abnormal return of the mutual fund portfolio. The advantage of using the factor model to measure performance is that it can not only indicate the stock selection ability but also the risk level of the portfolio. The risk of the portfolio will be indicated by the regression coefficient $\beta_{\mathrm{p}}$ which measures the sensitivity to the risk factors..$^{10}$

In this paper, we choose two benchmarks to estimate the abnormal performance. The first one

${ }^{10}$ For a partial review of the papers using the multi-factor model to evaluate the mutual funds returns, see Elton (1993) et al and Gruber (1996)'s "four index risk" adjustment procedure. Blake and Timmermann (1998) used the multi-factor model to evaluate the European mutual fund performance. 
is a standard single-factor, CAPM approach. The second one is based on Fama and French's (1993) three-factor model. The three factors are: an excess market return factor $\left(\mathrm{R}_{\mathrm{M}}-\mathrm{R}_{\mathrm{F}}\right)$, a size factor (SML), and a book-to-market (HML) factor. The size and book-to-market factors are proxies for distress since distressed firms (i.e., small size and high book-to-market) may be more sensitive to changes in certain business cycle factors, like changes in credit conditions, than are firms that are less financially vulnerable. Therefore, the SMB and HML factors measure the risk premium associated with the small and value stocks. Development of the mimicking portfolio for the factors is postponed to the next section of the paper.

The single factor (CAPM) performance evaluation model is:

$$
\mathrm{R}_{\mathrm{pt}}=\alpha_{\mathrm{p}}+\boldsymbol{\beta}_{\mathrm{pm}}\left(\mathrm{R}_{\mathrm{imt}}-\mathrm{R}_{\mathrm{ift}}\right)+\epsilon_{\mathrm{pt}}
$$

and the three-factor performance evaluation model is:

$$
\mathrm{R}_{\mathrm{pt}}=\alpha_{\mathrm{p}}+\beta_{\mathrm{pm}}\left(\mathrm{R}_{\mathrm{imt}}-\mathrm{R}_{\mathrm{ift}}\right)+\beta_{\mathrm{ps}} \mathrm{SMB}_{\mathrm{it}}+\beta_{\mathrm{ph}} \mathrm{HML}_{\mathrm{it}}+\epsilon_{\mathrm{pt}}
$$

where

$\mathrm{R}_{\mathrm{pt}}=$ excess return on portfolio $\mathrm{p}$ in period $\mathrm{t}$ (net of risk free rate).

$\mathrm{R}_{\mathrm{ift}}=$ risk free rate for country $\mathrm{i}$ in period $\mathrm{t}$.

$\mathrm{R}_{\mathrm{imt}}=$ return on the market for country $\mathrm{i}$ in $\mathrm{t}$.

$\mathrm{SMB}_{\mathrm{it}}=$ return on the small minus big portfolio for country $\mathrm{i}$ in period $\mathrm{t}$.

$\mathrm{HML}_{\mathrm{it}}=$ return on the high book-to-market less low book-to-market portfolio for country $\mathrm{i}$ in $\mathrm{t}$. 
$\mathrm{i}=$ country index equal to 1 if Canadian equity portfolio and equal to 2 if U.S. equity portfolio.

$\epsilon_{\mathrm{pt}}=$ error term with mean zero and variance $\sigma_{\mathrm{p}}^{2}$.

\subsection{Development of the Mimicking Portfolios}

The proxy for the Canadian market factor is the total value weighted return of TSE stocks less the return on the 30-day T-Bills. The other two variables used in the time-series regressions include the returns on two mimicking portfolios for size risk (SMB) and the book-to-market (HML) risk. The methodology used to develop the Canadian factors is based on Fama and French's (1993) work which we briefly summarize below. ${ }^{11}$

A sample of firms is first created which have data available on both the CFMRC/TSE Database and the Compustat Canadian Database over the June 1985 through June 1998 period. The firms are then ranked by two characteristics: the size (market value) of the firm's equity and the bookto-market ratio (BM). The median size is used to split the stocks into two size groups: small and big. The firms are also divided into three book-to-market groups based upon the breakpoints for the bottom 30\%(Low), middle 40\% (Medium), and top 30\% (High) of the ranked values of BM.

The firms are then sorted into cells. The two groups for the size and three groups for the BM give a total of six cells: small size/low BM, small size/medium BM, small size/high BM, big size/low $\mathrm{BM}$, big size/medium BM and big size/high BM. The small minus big (SMB) portfolio is meant to mimic the return factor related to size preserving the exposure to the BM characteristic while the high minus low (HML) portfolio is mean to mimic the return factor related to the book-to-market of equity preserving the exposure to the size characteristic. The mimicking portfolios' returns are calculated

\footnotetext{
${ }^{11}$ Refer to Berkowitz (2000) for a complete description of the development of the Canadian factors.
} 
as:

$\mathrm{SMB}$ return $=1 / 3[($ small size $/$ high $\mathrm{BM}$ portfolio return - large size/high BM portfolio return) + (small size/medium BM portfolio return-large size/medium BM portfolio return) + (large size /low BM portfolio return-large size/low BM portfolio return)] and

$\mathrm{HML}$ return $=1 / 2[$ (high $\mathrm{BM} /$ large size portfolio return - low $\mathrm{BM} /$ large size portfolio return $)+($ high $\mathrm{BM} /$ small size portfolio return - low BM/small size portfolio return)]

The proxy for the U.S market risk premium factor is the total value weighted return of the CRSP stocks less the return on the 30-day U.S. TBill rate. For the U.S. market, SMB and HML are the mimicking portfolio returns used in Fama and French (1993). ${ }^{12}$ The summary statistics for the three Canadian equity factors are provided in Table $4 \mathrm{a}$ while Table $4 \mathrm{~b}$ provides the summary statistics for the U.S. equity factors. ${ }^{13}$ A comparison of these tables shows that the Canadian market risk premium is about one-third of the U.S. market risk premium. At the same time, the size and book-to-market factors are significantly greater for the Canadian market, suggesting, on average, smaller valueoriented firms in Canada and larger growth-oriented firms in the U.S.

\subsection{Performance Evaluation Results}

To examine the differential performance of the mutual funds managed by publicly-traded and private management companies, we construct equally weighted portfolios of the net asset value returns for the Canadian equity funds, Canadian balance funds, and the U.S. equity funds for each

\footnotetext{
12 Thanks are due to Eugene Fama for providing the SMB and HML factors.

13 Refer to Berkowitz (2000) for a detailed study of the quality of the Canadian mimicking portfolios' returns.
} 
type of management company. For the U.S. equity funds we make a slight adjustment. Because their return is measured in Canadian dollars and subject to exchange rate variation, we adjust the return into U.S. dollar equivalent returns using the formula:

$$
\mathrm{R}_{\mathrm{t}}^{\mathrm{US}}=\left(1+\mathrm{R}_{\mathrm{t}}^{\mathrm{CN}}\right) /\left(1+\Delta \mathrm{EXC}_{\mathrm{t}}\right)-1
$$

where $R_{t}{ }^{u S}$ is the return of equity funds invested in the U.S. measured in U.S dollar in time $t ; R_{t}^{C N}$ represents the returns of equity funds invested in the U.S measured in Canadian dollars in time t; and $\triangle \mathrm{EXC}_{\mathrm{t}}$ is the appreciation/depreciation rate of the Canadian dollar vs U.S dollar in time $\mathrm{t}$.

Table 5 reports the performance evaluation results for the mutual funds managed by the publicly-traded management companies. For the Canadian equity funds, Canadian balanced funds and the Canadian funds invested in U.S. equities, the risk-adjusted returns appear to underperform the benchmark whether they are evaluated using the single-factor or the three-factor model. From the three-factor model, we can compare the relative risk premiums associated with each of the three factors across types of funds. First, we see that the Canadian equity funds have a higher positive coefficient on the excess market return than do the Canadian balanced funds. Also, Canadian equity funds have a positive coefficient on the size factor and a negative coefficient on the book-to-market factor while the Canadian balanced funds have a negative coefficient on the size factor and a positive coefficient on the book-to-market factor. ${ }^{14}$ This result suggests that the Canadian equity funds hold

\footnotetext{
${ }^{14}$ To formally test whether the betas of Canadian equity funds are different from those of Canadian balanced funds, we regress the difference in the return of Canadian equity funds and Canadian balanced funds on the three factors: $R_{e q}-R_{\text {bal }}=\alpha+\beta_{\mathrm{m}}\left(\mathrm{R}_{\mathrm{mt}}-\mathrm{R}_{\mathrm{ft}}\right)+\beta_{\mathrm{s}} \mathrm{SMB}_{\mathrm{t}}+\beta_{\mathrm{h}} \mathrm{HML}_{\mathrm{t}}+\epsilon_{\mathrm{t}}$, where $\mathrm{R}_{\mathrm{eq}}$ is the return of equity funds and $R_{\text {bal }}$ is the return of the balanced funds. Even though not reported here, the results indicate that factor loadings for the market and size factors are positive and significantly different from zero, while the loading for the book-tomarket factor is negative and significantly different from zero.
} 
more market sensitive, small and growth-oriented stocks than Canadian balance funds, which is consistent with how we expect these funds to act according to the different objectives of equity funds and balance funds. ${ }^{15}$ Second, Canadian equity funds and Canadian funds invested in U.S. equities are both influenced significantly by the three common equity risk factors: the market factor, the size factor and the book-to-market factor. ${ }^{16}$ These results suggest that the three factor model provides a more complete measure of mutual fund performance than does the single factor model and because of this, we focus the remaining analysis on the results from the three-factor model. The three-factor model suggests that the Canadian equity funds, Canadian balanced funds and U.S. equity funds managed by the publicly-traded management companies underperform by $0.32 \%, 0.42 \%$ and $0.40 \%$ per/month which is approximate $3.84 \%, 5.04 \%$ and $4.8 \%$ per year over the sample period. ${ }^{17}$

The corresponding regression results for the three types of funds managed by the six private management companies are provided in Table 6. Focusing on the three factor model, the abnormal returns of Canadian equity funds, Canadian balanced funds and Canadian funds invested in U.S. equities managed by the public management companies are lower than those of the privately managed funds by $2.04 \%, 0.48 \%$ and $0.12 \%$ per year. ${ }^{18}$ Examining the signs of the regression coefficients of

15 The primary objective of balanced funds is to provide a mixture of safety, income and capital appreciation, while the primary objective of the equity funds is capital gains. Because of this, equity funds usually adopt more aggressive investment strategies than balanced funds.

${ }^{16}$ All coefficients are significant at the 95\% confidence level except for the coefficient of HML for Canadian equity funds which is significant at the $93 \%$ confidence level,

${ }^{17}$ We simply multiply the monthly risk adjusted return by 12 to get the annual risk adjusted return.

18 Table 7 shows that the risk-adjusted returns of the Canadian equity funds managed by publicly-traded management companies are significantly lower than the risk-adjusted returns of the Canadian equity funds managed by the private management companies. At the same time, the risk-adjusted returns of the Canadian balanced funds and Canadian funds invested in U.S. equity securities do not appear to significantly differ as a result of ownership. 
the SMB and HML variables in Table 5 and Table 6, one can see that the publicly-traded management companies and private management companies have similar investment styles. The Canadian equity funds and Canadian funds invested in U.S. equities tend to hold small, growth-oriented stocks while the Canadian balanced funds hold large, value stocks.

The results in Tables 5 and 6 also suggest that Canadian equity funds managed by publiclytraded management companies and private management companies are both significantly influenced by market risk and size risk. In order to see if their risk factor loadings are significantly different, we regress the difference in the returns of the Canadian equity funds managed by the publicly-traded management companies and the Canadian equity funds managed by the private management companies on the three factors, i.e.,

$$
R_{t}^{P U B}-R_{t}^{P R I}=\alpha+\beta_{m}\left(R_{m t}-R_{f t}\right)+\beta_{s} S M B_{t}+\beta_{h} H M L_{t}+\epsilon_{t}
$$

where $\mathrm{R}_{\mathrm{t}}^{\mathrm{PUB}}$ is the return of the Canadian equity funds managed by the publicly-traded management companies in $t$ and $\mathrm{R}_{\mathrm{t}}^{\mathrm{PRI}}$ is the return of the Canadian equity funds managed by the private management companies in $\mathrm{t}$. The results in Table 7, panel A, show that the regression coefficient for the size factor is positive and significantly different from zero at the $95 \%$ confidence level, while other factor loadings are not significantly different from zero. These results also indicate that the Canadian equity funds held by the publicly-traded management companies have a significantly greater loading on the size factor than do the Canadian equity funds managed by the private management companies. Since equity funds primarily invest in common shares and are well diversified, we would not expect to see their market betas to be significantly different. Hence, their risk tendency could be best reflected in their loading for the size factors. 
Panel B in Table 7 shows that the market factor has a significant effect in explaining the difference in the returns of balance funds managed by the publicly-traded management companies and private management companies. These results are also reasonable given the characteristics of balanced funds. Since the primary goals of these funds are safety and capital gains, they typically invest a large part of their assets in the fixed income securities and less aggressive stocks such as large cap stocks. Hence, the market beta is the relevant risk indicator for balanced funds. The market beta will reflect how large a portion of the assets of the balanced funds is invested in stocks and how sensitive are those stocks to movements in the market.

Panel C provides a similar comparison for Canadian mutual funds investing in U.S. equity securities. The results are roughly similar to those for the Canadian equity funds in panel A and suggest that Canadian equity funds investing in U.S. equity securities managed by publicly traded companies have a greater loading on the size factor than do their privately managed counterparts.

In order to provide further evidence on the differences of the risk sensitivities between publictraded management companies and private management companies, we regress the individual fund's return on the three factors. Table 8 summarizes the percentage of the funds with significantly positive risk loadings on the three factors at the $95 \%$ confident level. Each of the funds in the sample managed by publicly-traded and private-owned managed management companies are significantly subjected to market risk. However, $60.5 \%, 10.1 \%$ and $62.6 \%$ of Canadian equity funds, Canadian balanced funds and Canadian funds investing in U.S. securities managed by the publicly-traded management companies have significant loadings on the size factor respectively. The percentages of the corresponding funds managed by the private-traded management are consistently lower at $52.4 \%$, $0 \%$ and $52.9 \%$. In addition, $29.9 \%, 60 \%$ and $23.1 \%$ of the Canadian equity funds, Canadian balanced 
funds and Canadian funds investing in U.S. managed by the publicly-traded management companies have significantly positive loadings on the book-to-market factor respectively, while only $15.5 \%$, $44.4 \%$ and $22.4 \%$ of the corresponding funds managed by the private management companies have significantly positive loadings on the book-to-market factor, respectively.

The above evidence presents a picture which suggests that mutual funds managed by publiclytraded management companies do not over-perform, and indeed under-perform the funds managed by privately-owned management companies in the Canadian equity fund category. Furthermore, the funds managed by these publicly-traded management companies also tend to invest in riskier assets than do the mutual funds managed by the privately-owned management companies. Certainly, an important question to ask is what are the reasons for these differences?

\section{How Does Ownership Affect Performance?}

There are at least two advantages for management companies to choose to be publicly-traded. First, listing can improve the company's access to capital. In order to benefit from the rapid expansion within the mutual fund industry, management companies have to set up new branches, market their products, etc. Listing is an important way of increasing their funding opportunities. In Canada, among the top five management companies, three are publicly-traded management companies and the other two are bank-run management companies. ${ }^{19}$ A second reason for choosing to be publicly-traded is that risk can be spread over a larger number of owners. In a world in which the company is owned

\footnotetext{
${ }^{19}$ Bank-run management companies can easily finance their business through their banking system. Also they can use the existing bank branch to market their service. Therefore, they need less cash to expand their business and have easy access to financing.
} 
by a single manager-owner, even though there are no agency costs, the sole shareholder bears all the investment risk and requires a higher discount rate in order to invest in a risky project. Hence risky projects are less valuable in this situation. Public ownership reduces each shareholder's stake within the company and essentially diversifies the shareholder's portfolio. Therefore, risky investments are more valuable for the shareholders of publicly-traded management companies. This risk spreading mechanism allows the shareholders of publicly-traded management companies to invest in riskier assets.

On the other side of the coin, there are also some disadvantages of choosing to be publiclytraded; otherwise, we would observe no private management companies in an ‘equilibrium' world. One disadvantage is that the operating costs of publicly-traded management companies may be higher than for private companies. The costs of the IPO, reporting and public disclosure represent significant outflows for publicly-traded companies. ${ }^{20}$ Because of this, management companies may have an incentive to increase their management fees in order to continue increasing their profit level, even though they know the higher management fees will reduce the return of the mutual funds they manage, which in turn will cause the funds to lose investment in the future. ${ }^{21}$ Second, the agency costs associated with publicly-traded firms are generally believed to be greater than those of privately-owned companies. Choosing to be publicly-traded will dilute ownership and in doing so, the owner has less control over the manager. The manager may then increase her excess perquisite

20 Depending on the size of the transaction, ten percent of the capital raised from the listing may be used to cover the cost for the listing. See Industry Canada: Business Turning Point: Going Public. Publication date: Oct 221999.

21 A number of researchers have shown this relationship, including Berkowitz and Kotowitz (1993, 2000), Ippolito (1992) and Chevalier and Ellison (1997), among others. 
consumption and thus the administrative fees for the mutual fund. A higher administrative fee will in turn reduce the performance of the mutual fund. Further, the remuneration paid to managers of management companies is based on the performance of the mutual funds they manage, investing in riskier assets increases the risk of the managers' portfolios. At the same time, investing in a riskier portfolio is more difficult and requires greater effort on the part of managers. ${ }^{22}$ Therefore, publicly-traded management companies must provide higher compensation for their managers. As a result, publicly-traded management companies may charge a higher management fee than the private management companies to compensate for their extra costs. The manager recognizes, however, that the higher management fee will reduce the net return of the mutual funds under management and hence the future cash inflow to the management companies. The manager must, therefore, trade-off these consequences when deciding on the fee structure.

To analyze the effect of ownership on the performance of the management companies, we concentrate on the management fee, administrative fee and the risk of the assets under management. We have already shown in the last section that the publicly-traded management companies tend to hold riskier assets than privately-owned management companies, which is consistent with the risk spreading argument. In this section, we compare the management fees and expense ratios charged by the publicly-traded management companies and private companies to shed some light on the agency cost issue. From Table 3, we can see that the average management fee of the funds managed by publicly-traded management companies is much higher than the management fee of the funds managed by private management companies. The management fees of the Canadian equity funds,

22 For example, it is much more difficult to choose the securities within a portfolio of bio-technology stocks than in an index fund. In turn, the more easily managed index fund charges a lower management fee than does an actively managed fund, such as bio-technology funds. 
Canadian balanced funds and Canadian equity funds invested in U.S. securities managed by the publicly-traded management companies are $122 \%, 149 \%$ and $113 \%$, respectively, more than those managed by the private management companies. At the same time, the variation in management fees for the mutual funds managed by the publicly-traded management companies is less for those funds managed by privately managed companies. The expense ratios, which include the management fees and administrative fees, are, like the management fees, uniformly greater for publicly-owned management companies. However, the administrative fees of the mutual funds managed by the publicly-traded management companies are not significantly greater than those of the mutual funds managed by the privately-owned management companies. The average administrative fees of the Canadian equity funds and balanced funds managed by the publicly-traded management companies are even lower than those of the Canadian equity funds and balanced funds managed by the privatelyowned management companies.

The traditional belief is that the level of the fee is related to the fund characteristics, such as size of fund, number of funds within the management company complex, fund age, fund type and service delivery. ${ }^{23}$ To see if management company ownership affects this relationship, we run the following regression:

$$
\begin{aligned}
\mathrm{FEE}_{\mathbf{i}}=\mathbf{a}+\mathbf{b}_{1} \log \left(\mathrm{SIZE}_{\mathrm{i}}\right)+\mathrm{b}_{2} \log \left(\mathrm{MGTSIZE}_{\mathrm{i}}\right)+\mathbf{b}_{3} \mathrm{AGE}_{\mathrm{i}}+\mathbf{b}_{4} \mathrm{LOAD}_{\mathrm{i}} \\
+\mathrm{b}_{5} \mathrm{TYPE}_{\mathrm{i}}+\mathrm{b}_{6} \mathrm{MGT}_{\mathrm{i}}+\epsilon_{\mathrm{i}}
\end{aligned}
$$

where the dependent variable $\mathrm{FEE}_{\mathrm{i}}$ is the fee of mutual fund $\mathrm{i}$ (expense ratio, management fee or administrative fee); SIZE $_{\mathrm{i}}$ is the mutual fund i's total net asset value; MGTSIZE $_{\mathrm{i}}$ is the size of mutual

23 See, for example, Baumol et al (1990) and Ferris and Chance (1987). 
fund i's management company measured by the number of the mutual funds managed by that management company; $A G E_{i}$ is the age of mutual fund $\mathrm{i}, \mathrm{LOAD}_{\mathrm{i}}$ is a dummy variable which is equal to 1 if fund $\mathrm{i}$ is a load fund and is equal to 0 if the fund is a no-load fund; $\mathrm{TYPE}_{\mathrm{i}}$ is a dummy variable which is equal to 1 if fund $\mathrm{i}$ is an equity fund and is equal to 0 if the fund is a balanced fund; $\mathrm{MGT}_{\mathrm{i}}$ is a dummy variable which is equal to 1 if the fund i's management company is publicly-traded and is equal to 0 if the fund's management company is private.

Table 9 reports the cross-sectional regressions used to explain the variation in management fees, management expense ratios and administrative fees. Looking first to the determinants of the management fees, the negative coefficients for the $\log \left(\mathrm{SIZE}_{\mathrm{i}}\right)$ and $\log \left(\mathrm{MGTSIZE}_{\mathrm{i}}\right)$ variables imply that there exists economies of scale and economies of scope for the mutual fund management even though they are not significant. The larger is the size of the mutual fund and greater are the number of funds managed by the management company, the lower is the fee charged by the management company. The coefficients of both $\mathrm{AGE}_{\mathrm{i}}$ and $\mathrm{LOAD}_{\mathrm{i}}$ are also not significant. The only significant variables are the type of mutual fund and whether or not the management company is publicly-traded. The coefficient for the dummy variable $\mathrm{TYPE}_{\mathrm{i}}$ is 0.348 and is significant at the $95 \%$ confidence level indicating that the management fees for equity funds on average are $0.348 \%$ higher than those for balance funds. This is not surprising since the equity funds are riskier and harder to manage and must be compensated through higher management fees. Particularly interesting is that the dummy variable $\mathrm{MGT}_{\mathrm{i}}$ has a significant coefficient with a positive value 0.494 . This result suggests that publicly-traded management companies on average charge $0.494 \%$ per year more in management fees than do the privately-owned management companies, likely as a result of some combination of higher operating and agency costs than their privately-owned counterparts. 
The results for the determinants of the expense ratio are also interesting. The significant coefficient for $\log \left(\right.$ MGTSIZE $\left._{\mathrm{i}}\right)$ and insignificant coefficient for $\log \left(\mathrm{SIZE}_{\mathrm{i}}\right)$ indicate that the funds have significant economies of scope but not significant economies of scale. This suggests that Canadian mutual funds are too small compared to, for example, mutual funds in the U.S., which have been found to have both significant economies of scale and economies of scope. ${ }^{24}$ The administrative fee, moreover, does not significantly depend on the ownership of the management company, suggesting that it is not necessarily the case that the diffusion of ownership that characterizes publicly-traded management companies increases the excess perquisite consumption of the managers.

The higher management fees shown in Table 3 for the mutual funds managed by publicly-traded management companies could be an important factor, however, in explaining their risk adjusted returns.$^{25}$ If we add back the difference in management fees to the difference in risk adjusted returns of the mutual funds managed by the publicly-traded management companies and private management companies, we find that the risk- adjusted returns of the Canadian balanced funds and Canadian equity funds invested in U.S. securities managed by the publicly-traded management companies are almost the same as those for the funds managed by private management companies. ${ }^{26}$ However, even after adding back the difference in MERs, the risk-adjusted return of the Canadian equity funds managed by publicly-managed companies are still lower than that of Canadian equity

\footnotetext{
${ }^{24}$ See Baumol et al (1990).

${ }^{25}$ Carhart (1997) has also shown that the high fees can explain the poor performance of certain funds.

${ }^{26}$ From Table 3, Canadian balanced funds managed by publicly-traded management companies have an annual MER of $1.73 \%$ while their privately managed counterparts have an annual MER of $1.16 \%$. The difference is $.047 \%$ per month which is approximately the difference between the $\alpha$ coefficient in Table 5 for Canadian balanced funds of -.0042 and the corresponding $\alpha$ value of -.0038 in Table 6 for privately managed funds. Similarly, for Canadian equity funds invested in U.S. securities, the monthly difference in MERs is .019\% while the difference in $\alpha$ coefficients is approximately .01\%.
} 
funds managed by private management companies by approximately $1.7 \%$ per year.

Our results also lead us to question the effectiveness of mutual fund boards of directors. The funds' boards are expected to consider the fund performance when they negotiate with management companies on the fee level. They must also consider comparative fees paid by similar funds. The higher fees together with lower performance of the publicly-traded management companies suggests that the mutual funds' boards are not effective monitors. In addition, typically, each mutual fund has one board of directors. If each board of directors is an active monitor on behalf of the unitholders, we would expect to see some variation in the management fee among different mutual funds since each of the funds has different characteristics. The small variation of management fees for the funds managed by the publicly-traded management companies also suggests that mutual fund boards of directors have not been particularly effective in negotiating fees with the management companies.

The interesting question is then: If mutual funds managed by publicly-traded management companies have higher fees but do not have superior performance than those managed by the private management companies, how can they attract investors within the competitive mutual fund industry? ${ }^{27}$ One explanation is that investors lack the skill to calculate risk-adjusted returns. The mean monthly raw returns over the entire sample period on the Canadian equity funds, Canadian balanced funds and the U.S. equity funds managed by the publicly-traded management companies are $1.30 \%, 0.72 \%$ and $1.74 \%$, respectively, while those managed by the private management companies are $1.49 \%, 0.74 \%$ and $1.77 \%$, respectively. The differences in the unadjusted returns are very small. If investors rely on

\footnotetext{
${ }^{27}$ This question is related to another puzzle about the growth of actively managed mutual funds. In his presidential address to American Finance Association, Gruber (1996) showed that investors can be better off by choosing index funds rather than funds which are actively managed since the index funds have better average performance and lower fees. However, actively managed funds have still grown substantially in the U.S. over the past decade.
} 
past raw returns to select mutual funds, it would be difficult for them to differentiate between the mutual funds managed by publicly-traded management and the mutual funds managed by the private management companies. A second reason may be investors' ignorance of the fees they pay to the management companies. In a survey by Capon et al. (1996), the authors showed that the majority of investors are naive. Investors typically lack the knowledge of the investment strategies or financial details of their investments and usually do not pay much attention to the fees charged by their mutual funds. Therefore, even though the $0.49 \%$ per year difference in the management fee means a lot to the management companies, it may be ignored by investors at the individual level. Finally, it may be due to the existence of a disadvantaged mutual fund investor clientele, which is proposed by Gruber (1996) when he explains the puzzle for the growth of the actively managed funds. According to Gruber, the disadvantaged clientele is made up of unsophisticated investors who make investments based upon some factors, such as advertising, as opposed to the performance of the funds. Also included in this group are those investors who have pension plans and are restricted to be the part of some funds as well as the tax disadvantaged investors who are unable to effectively move money because of capital gains taxes. Further, not to be overlooked, is that listing could make publicly-trade management companies in general more visible than the private management companies. Indeed, because of the existence of the disadvantage investors, visibility may be a factor in stimulating sales of the mutual funds managed by publicly-trade management companies .

\section{Summary and Conclusions}

This paper has examined if and how ownership affects the risk and performance of mutual funds managed by management companies. We have shown that the risk-adjusted returns of the 
mutual funds managed by the publicly-traded management companies are not higher than those of the mutual funds managed by private management companies and in fact significantly underperform in the Canadian equity funds category. The mutual funds managed by publicly-traded management companies tend to invest in riskier securities and on average charge higher management fees than do privately-owned management companies. This phenomenon is consistent with the risk reduction argument made by Smith and Stultz (1985).

Publicly-traded management companies also incur higher agency costs than do privatelyowned management companies, take on more risk and in doing so, undertake greater effort to invest in risky assets which requires greater compensation. The publicly-traded management companies will therefore tend to charge higher management fees than the private management companies. The higher management fees, however, lower risk-adjusted returns and are expected to have a negative impact on future investment in these funds.

The puzzle is that if the funds managed by publicly-owned management companies do not achieve higher performance levels but charge higher management fees, why do investors continue to place their money in these funds? A possible explanation for the existence of this phenomenon in the competitive mutual fund industry is that the shareholders of the publicly-traded management companies take advantage of the mutual fund unitholders' ignorance of management fees, their inability to calculate risk-adjusted returns and their disadvantaged position.Given that it is still controversial whether or not fund managers have superior stock picking ability, and the generally accepted fact that fees are an important determinant of fund performance, our results suggest it may be, ceteris paribus, that investors should avoid funds managed by publicly-traded management companies when they decide in which funds to invest. 
Acknowledgment: Thanks are due to Varouj Aivazian, Raymond Kan, Alex Maynard, Angelo Melino, and Aloysius Siow for their helpful comments. All errors remain the responsibility of the authors. 


\section{References}

Baumol, W.J., Goldfeld, S.M., Gordon, L.A. and Koehn, M.F. (1990) The Economics of Mutual Fund Markets: Competition Versus Regulation, Rochester Studies in Economics and Policy Issues, Kluwer Academic Publishers.

Berkowitz, M. K. and Qiu, J.(2001) Common Risk Factors in Explaining Canadian Equity Returns, Working Paper, University of Toronto.

Berkowitz, M. K, and Kotowitz, Y. (1993) Incentives and Efficiency in the Market for Management: A Study of Mutual Funds, Canadian Journal of Economics (26) 850-866.

Berkowitz, M. K, and Kotowitz, Y. (2000) Investor Risk Evaluation in the Determination of Management Incentives in the Mutual Fund Industry, Journal of Financial Markets, (3) 365387.

Berkowitz, M. K, and Kotowitz, Y. (2001) Managerial Quality and the Structure of Management Expenses in the U.S. Mutual Fund Industry, International Review of Economics and Finance, forthcoming.

Blake, D., and Timmermann, A. (1998) Mutual Fund Performance: Evidence from the UK, European Finance Review (2) 57-77.

Calvert, A. L and Lefoll (1981) J, Performance and Systematic Risk Stability of Canadian Mutual Funds under Inflation, Journal of Business Finance and Accounting 8, no 2 (summer): 279-289.

Capon, N., Fitzsimons, G., Prince, R. (1996) An Individual level Analysis of the Mutual Fund Investment Decision, Journal of Financial Services Research (10) 59-82.

Carhart, M. (1997.) On Persistence in Mutual Fund Performance, Journal of Finance (52) 57-82.

Chen.C.R., Steiner. T. L. and Whyte. A. M (1998) Risk Taking Behavior and Managerial Ownership in Depository Institution, Journal of Financial Research, 21, 1-16.

Chevalier,J., Ellison, G. (1997) Risk Taking by Mutual Funds as a Response to Incentives, Journal of Political Economy 105 (6) 1167-1200.

Cole, R. and Mehran, H. (1998) The Effect of Change in Ownership Structure on Performance: Evidence from the Thrift Industry Journal of Financial Economics (50) 291317. 
Del Guercio, D. and Tkac, P.A. (2000) The Determinants of the Flow of Funds of Managed Portfolios: Mutual Funds versus Pension Funds, Federal Reserve Bank of Atlanta, Working Paper 2000-21, 1-46.

Demetz, H.(1983) The Structure of Ownership and the Theory of the Firm Journal of Law and Economics (26) 375-390.

Demsetz, H., and Lehn, K. (1985) The Structure of Corporate Ownership: Causes and Consequences, Journal of Political Economy (93) 1155-1177.

Dhingra, H. L (1978) Portfolio Volatility Adjustment by Canadian Mutual Funds, Journal of Finance and Accounting 5, no 4 (winter): 305-333.

Fama, E.F and French, K.R. (1993) Common Risk Factors In the Returns On Stocks and Bonds, Journal of Financial Economics (33) 3-56.

Ferris, S.P. and Chance, D.M. (1987) The Effect of 12b-1 Plans on Mutual Fund Expense Ratios: A Note, Journal of Finance (42) 1077-1082.

Galai, D. and Masulis, R. W (1976) The Option Pricing Model and the Risk Factor of Stock, Journal of Financial Economics, 3, 53-81.

Grant, D. (1976) Investment Performance of Canadian Mutual Funds: 1960-1974, Journal of Business Administration 8, no 1 (Fall): 1-9.

Gruber, M. J. (1996) Another Puzzle: The Growth In Active Managed Mutual Funds, Journal of Finance (47) 1977-1984.

Himmelberg, C.P., Hubbard, R.G., Pulia, D. (1999) Understanding the Determinants of Managerial Ownership and the Link Between Ownership and Performance, Journal of Financial Economics (53) 353-384.

Ippolito, R. (1992) Consumer Reaction to Measures of Poor Quality: Evidence from the Mutual Fund Industry, Journal of Law and Economics (35) 45-70.

Jensen, M., Meckling, W. (1976) Theory of the Firm: Managerial Behavior, Agency Costs and Ownership Structure, Journal of Financial Economics (3) 305-360.

Lehmann, B.N. and Modest, D.M. (1987) Mutual Fund Performance Evaluation: A Comparison of Benchmarks and Benchmark Comparisons, 1987 Journal of Finance (42) 233-265.

May, D. O. (1995) Do Managerial Motives Influence Firm Risk Reduction Strategies, Journal 
of Finance 50, 1291-1308.

McConnel, J.J., and Servaes, H. (1990) Additional Evidence On Equity Ownership and Corporate Value, Journal of Financial Economics (27) 595-613.

Morck, R., Shleifer, A., Vishny, R. (1988) Management Ownership and Market Valuation, Journal of Financial Economics (20) 293-315.

Smith, C. W. and Stulz, R. M. (1985) The Determinants of Firms' Hedging Policies, Journal of Financial and Quantitative Analysis, 20, 443-457.

Sirri, E.R. and Tufano, P. (1998) Costly Search and Mutual Fund Flows, Journal of Finance (53) $1589-1622$.

Zhang, G. (1998.) Ownership Concentration, Risk Aversion and the Effect of Financial Structure on Investment Decisions, European Economic Review (42) 1751-1778. 


\section{Table 1}

\section{Canadian Mutual Funds Industry-*IFIC Members}

\begin{tabular}{|ccccc|}
\hline Year & Net Assets at Market & Net New Sales & Number of Funds Number of Unitholders \\
1991 & 49,916 & 12,481 & 505 & $4,533,686$ \\
1993 & 114,598 & 34,863 & 663 & $8,928,661$ \\
1995 & 146,228 & 10,272 & 916 & $15,295,121$ \\
1997 & 283,159 & 64,387 & 1023 & $32,826,069$ \\
1999 & 389,696 & 29,340 & 1328 & $45,752,433$ \\
\hline
\end{tabular}

*As of September 1991, IFIC Members represent $97 \%$ of assets under management in Canada.

Source: The Investment Funds Institute of Canada 


\section{Table 2}

\section{Management Companies Data Set Summary Statistics}

The table reports the descriptive statistic for management companies' data set and time-series averages from June 1985 to April 1998. TNA is the total net asset value. Mgt Fee is the percentage management fee for the management companies. Exp Ratio is the management fee plus administrative expense divided by average NAV. Number of Fund is the number of the funds managed by the management company. Date of listing is the date that the management company became publicly-traded.

\begin{tabular}{|c|c|c|c|c|c|c|}
\hline Company Name & $\begin{array}{l}\text { Number of } \\
\text { Funds }\end{array}$ & $\begin{array}{l}\text { Avg TNA } \\
(\$ \text { million })\end{array}$ & $\begin{array}{l}\text { Avg Mgt Fee } \\
\text { (\%/Year) }\end{array}$ & $\begin{array}{c}\text { Avg Exp Ratio }(\% \\
\text { year })\end{array}$ & $\begin{array}{l}\text { Public / } \\
\text { Private }\end{array}$ & $\begin{array}{l}\text { Date of } \\
\text { Listing }\end{array}$ \\
\hline AGF Management Ltd. & 42 & 363.6 & 2.1 & 2.3 & Public & $9 / 1968$ \\
\hline BPI Financial Corp. & 34 & 149.1 & 1.8 & 2.5 & Public & $8 / 1994$ \\
\hline CI Fund Management Inc. & 58 & 149.7 & 1.8 & 2.4 & Public & $7 / 1994$ \\
\hline Investors Group Corp. & 50 & 880.7 & 1.7 & 2.5 & Public & $12 / 1986$ \\
\hline Mackenie Financial Corp. & 64 & 585.8 & 1.2 & 1.3 & Public & $10 / 1982$ \\
\hline Trimark Financial Corp & 30 & 882.3 & 1.6 & 2.2 & Public & $5 / 1992$ \\
\hline AIC Limited & 40 & 210.6 & 2.0 & 2.3 & Private & $*$ \\
\hline Royal Mutual Funds Inc. & 33 & 731.7 & 1.3 & 1.8 & Private & $*$ \\
\hline Fidelity Investments Canada Limited & 23 & 364.5 & 1.9 & 2.1 & Private & $*$ \\
\hline TD Asset Management & 43 & 384.5 & 1.5 & 1.9 & Private & $*$ \\
\hline CIBC Securities Inc. & 55 & 407.3 & 1.2 & 1.3 & Private & $*$ \\
\hline Templeton Management Limited & 14 & 430.8 & 1.5 & 1.8 & Private & $*$ \\
\hline
\end{tabular}




\section{Table 3}

\section{The Sample Funds}

The table reports the summary statistics for the funds included in our analysis. They are equity funds and balanced funds invested in Canada and Equity fund invested in the U.S managed by the management companies in Table 1. Number is the total number of the funds in each group. TNA is the average total net asset value of the funds. Mgt Fee is the average management fee of the funds. ExpRatio is the average expense ratio of the fund. The expense ratio is the management fee plus other administrative fee. Age is the average age of the funds.

\section{Publicly-traded Management Companies}

\begin{tabular}{|c|c|c|c|c|c|c|c|}
\hline & $\begin{array}{l}\text { Number } \\
\text { of Funds }\end{array}$ & $\begin{array}{l}\text { Age of } \\
\text { Fund }\end{array}$ & $\begin{array}{c}\text { TNA } \\
\text { (\$ million) }\end{array}$ & $\begin{array}{c}\text { Mgt } \\
\text { Fee }(\%)\end{array}$ & $\begin{array}{l}\text { Std. Dev. of } \\
\text { Mgt. Fee }\end{array}$ & $\begin{array}{l}\text { Exp Ratio } \\
(\%)\end{array}$ & $\begin{array}{l}\text { Std. Dev. of } \\
\text { Exp. Ratio }\end{array}$ \\
\hline Canadian equity funds & 40 & 10.0 & 757.8 & 1.99 & 0.37 & 2.51 & 0.34 \\
\hline Canadian balanced funds & 16 & 14.3 & 849.1 & 1.73 & 0.72 & 2.42 & 0.40 \\
\hline \multirow[t]{3}{*}{$\begin{array}{l}\text { Canadian funds invested } \\
\text { in U.S. equities }\end{array}$} & 14 & 12.3 & 529.1 & 2.00 & 0.20 & 2.25 & 0.30 \\
\hline & \multicolumn{7}{|c|}{ Private-owned Management Companies } \\
\hline & $\begin{array}{l}\text { Number } \\
\text { of Funds }\end{array}$ & $\begin{array}{l}\text { Age of } \\
\text { Fund }\end{array}$ & $\begin{array}{c}\text { TNA } \\
\text { (\$ million) }\end{array}$ & $\begin{array}{l}\text { Mgt. } \\
\text { Fee (\%) }\end{array}$ & $\begin{array}{l}\text { Std. Dev. of } \\
\text { Mgt. Fee }\end{array}$ & $\begin{array}{l}\text { Exp Ratio } \\
(\%)\end{array}$ & $\begin{array}{l}\text { Std. Dev. of } \\
\text { Exp. Ratio }\end{array}$ \\
\hline Canadian equity funds & 26 & 6.4 & 754.5 & 1.63 & 0.61 & 2.12 & 0.50 \\
\hline Canadian balanced funds & 9 & 11.0 & 1185.0 & 1.16 & 0.90 & 2.07 & 0.78 \\
\hline $\begin{array}{l}\text { Canadian funds invested } \\
\text { in U.S. equities }\end{array}$ & 20 & 6.3 & 352.9 & 1.77 & 0.54 & 2.08 & 0.64 \\
\hline
\end{tabular}




\section{Table 4a}

\section{Summary Statistics for the Canadian Risk Factors, June 1985 to June 1998}

The market return $\left(\mathrm{R}_{\mathrm{m}}\right)$ is determined using the value-weighted TSE total stock returns. The risk-free rate $\left(\mathrm{R}_{\mathrm{F}}\right)$ is the 30-day return on Canada T-bills. SMB and HML are calculated using the Fama and French (1993) methodology with the CFMRC/TSE and COMPUSTAT Canadian Annual File data set. Total 157 months.

\begin{tabular}{|lcccccc|}
\hline Factor & Mean & Std. Dev. & t-statistic & \multicolumn{3}{c|}{ Cross Correlation } \\
\hline & & & & $\mathrm{R}_{\mathrm{m}}-\mathrm{R}_{\mathrm{F}}$ & $\mathrm{SMB}$ & $\mathrm{HML}$ \\
\cline { 4 - 7 } $\mathrm{R}_{\mathrm{m}}-\mathrm{R}_{\mathrm{F}}$ & 0.36 & 4.03 & 1.13 & 1.000 & & \\
$\mathrm{SMB}$ & 0.54 & 3.34 & 2.25 & 0.064 & 1.000 & \\
$\mathrm{HML}$ & 0.46 & 3.95 & 1.44 & 0.097 & -0.010 & 1.000 \\
\hline
\end{tabular}

Table 4b

\section{Summary Statistics for the U.S Risk Factors, June 1985 to June 1998}

The market return $\left(\mathrm{R}_{\mathrm{m}}\right)$ is determined using the value-weighted CRSP total stock returns. The risk-free rate $\left(\mathrm{R}_{\mathrm{F}}\right)$ is the 30-day return on the U.S. T-bills. SMB and HML are the mimicking portfolio returns for the size and book-to-market risk factors used in Fama and French (1993). Total 157 months

\begin{tabular}{|lcccccc|}
\hline Factor & Mean & Std. Dev. & t-statistic & \multicolumn{3}{c|}{ Cross Correlation } \\
\hline & & & & $\mathrm{R}_{\mathrm{m}}-\mathrm{R}_{\mathrm{F}}$ & SMB & HML \\
\cline { 4 - 7 } $\mathrm{R}_{\mathrm{m}}-\mathrm{R}_{\mathrm{F}}$ & 0.93 & 4.12 & 2.77 & 1.000 & & \\
$\mathrm{SMB}$ & -0.23 & 2.55 & -1.13 & 0.137 & 1.000 & \\
HML & 0.21 & 2.31 & 1.14 & -0.447 & -0.271 & 1.000 \\
\hline
\end{tabular}




\section{Table 5}

\section{The Performance of the Mutual Funds Managed by the Publicly-traded Management Companies}

The table reports the performance evaluation of the mutual funds managed by the publicly-traded management companies using the one factor CAPM approach and a three-factor model as suggested by Fama and French (1993). For the one factor model, the abnormal return is measured by the alpha, which is the intercept in regressions for the excess returns of the funds on the excess return of the market return. The regression equation is:

$$
\mathrm{R}_{\mathrm{t}}-\mathrm{R}_{\mathrm{Ft}}=\alpha+\beta_{\mathrm{m}}\left(\mathrm{R}_{\mathrm{mt}}-\mathrm{R}_{\mathrm{Ft}}\right)+\epsilon_{\mathrm{t}}
$$

In the three factor model, the alphas are the intercepts in the regressions of the excess returns of the funds on the three factors, which are the market risk factor in time $t\left(R_{t}-R_{F t}\right)$, size factor in $t\left(S M B_{t}\right)$, and book to market factor in $\mathrm{t}\left(\mathrm{HML}_{\mathrm{t}}\right)$. The regression equation is:

$$
\mathrm{R}_{\mathrm{t}}-\mathrm{R}_{\mathrm{Ft}}=\alpha+\beta_{\mathrm{m}}\left(\mathrm{R}_{\mathrm{mt}}-\mathrm{R}_{\mathrm{Ft}}\right)+\beta_{\mathrm{s}} \mathrm{SMB}_{\mathrm{t}}+\beta_{\mathrm{h}} \mathrm{HML}_{\mathrm{t}}+\epsilon_{\mathrm{t}}
$$

The numbers in parentheses are t-statistics. Total 157 months.

Canadian Equity Funds Canadian Balanced Funds Cdn. Eq. Funds Invested in U.S.

\begin{tabular}{|ccccccc|}
\hline Intercept & CAPM & Three-Factor & $\underline{\text { CAPM }}$ & Three-Factor & $\underline{\text { CAPM }}$ & Three-Factor \\
& -0.0028 & -0.0032 & -0.0044 & -0.0042 & -0.0049 & -0.0040 \\
& $(-3.40)$ & $(-4.17)$ & $(-4.89)$ & $(-4.63)$ & $(-3.56)$ & $(-2.85)$ \\
$\mathrm{R}_{\mathrm{mt}}-\mathrm{R}_{\mathrm{Ft}}$ & 0.8094 & 0.8067 & 0.4642 & 0.4653 & 0.9204 & 0.8774 \\
& $(39.84)$ & $(42.68)$ & $(20.81)$ & $(20.99)$ & $(28.42)$ & $(24.58)$ \\
$\mathrm{SMB}_{\mathrm{t}}$ & & 0.1120 & & -0.0592 & & 0.1156 \\
& & $(4.99)$ & & $(-2.25)$ & & $(2.17)$ \\
$\mathrm{HML}_{\mathrm{t}}$ & & -0.0349 & & 0.0216 & & -0.1379 \\
& & $(-1.82)$ & & $(0.96)$ & & $(-2.11)$ \\
& & & & & & \\
Adj- $\mathrm{R}^{2}$ & 0.91 & 0.93 & 0.74 & 0.75 & 0.84 & 0.85 \\
\hline
\end{tabular}




\section{Table 6}

\section{The Performance of the Mutual Funds Managed by the Private Management Companies}

The table reports the performance evaluation of the mutual funds managed by the publicly-traded management companies using the one factor CAPM approach and a three-factor model as suggested by Fama and French (1993). For the one factor model, the abnormal return is measured by the alpha, which is the intercept in regressions for the excess returns of the funds on the excess return of the market return. The regression equation is:

$$
\mathrm{R}_{\mathrm{t}}-\mathrm{R}_{\mathrm{Ft}}=\alpha+\beta_{\mathrm{m}}\left(\mathrm{R}_{\mathrm{mt}}-\mathrm{R}_{\mathrm{Ft}}\right)+\epsilon_{\mathrm{t}}
$$

In the three factor model, the alphas are the intercepts in the regressions of the excess returns of the funds on the three factors, which are the market risk factor in time $t\left(R_{t}-R_{F t}\right)$, size factor in $t\left(S_{M B}\right)$, and book to market factor in $\mathrm{t}\left(\mathrm{HML}_{\mathrm{t}}\right)$. The regression equation is:

$$
\mathrm{R}_{\mathrm{t}}-\mathrm{R}_{\mathrm{Ft}}=\alpha+\beta_{\mathrm{m}}\left(\mathrm{R}_{\mathrm{mt}}-\mathrm{R}_{\mathrm{Ft}}\right)+\beta_{\mathrm{s}} \mathrm{SMB}_{\mathrm{t}}+\beta_{\mathrm{h}} \mathrm{HML}_{\mathrm{t}}+\epsilon_{\mathrm{t}}
$$

The numbers in parentheses are t-statistics. Total 157 months.

\begin{tabular}{|c|c|c|c|c|c|c|}
\hline & CAPM & Three-Factor & CAPM & $\underline{\text { Three-Factor }}$ & $\underline{\text { CAPM }}$ & $\underline{\text { Three-Factor }}$ \\
\hline \multirow[t]{2}{*}{ Intercept } & -0.0012 & -0.0015 & -0.0040 & -0.0038 & -0.0046 & -0.0039 \\
\hline & $(-1.19)$ & $(-2.02)$ & $(-4.74)$ & $(-4.48)$ & $(-2.73)$ & $(-2.16)$ \\
\hline \multirow{2}{*}{$\mathrm{R}_{\mathrm{mt}}-\mathrm{R}_{\mathrm{Ft}}$} & 0.7761 & 0.8221 & 0.4026 & 0.4038 & 0.9203 & 0.8921 \\
\hline & $(39.26)$ & (44.59) & (19.08) & (19.41) & $(22.84)$ & (19.38) \\
\hline \multirow[t]{2}{*}{$\mathrm{SMB}_{\mathrm{t}}$} & & 0.0671 & & -0.0667 & & 0.0368 \\
\hline & & $(3.06)$ & & $(-2.70)$ & & $(0.53)$ \\
\hline \multirow[t]{2}{*}{$\mathrm{HML}_{\mathrm{t}}$} & & -0.0050 & & 0.0254 & & -0.1066 \\
\hline & & $(-0.26)$ & & $(1.21)$ & & $(-1.27)$ \\
\hline Adj- $R^{2}$ & 0.89 & 0.93 & 0.70 & 0.72 & 0.71 & 0.77 \\
\hline
\end{tabular}

Canadian Equity Funds Canadian Balanced Funds Cdn Eq. Funds Invested in U.S. 


\section{Table 7}

\section{The Difference In the Risk Loadings Between the Mutual Funds Managed by the Publicly-traded Management Companies and Private Management Companies}

This table compares the risk loadings of Canadian equity funds, Canadian balanced funds, and Canadian equity funds investing in U.S. securities managed by publicly-traded management companies with the risk loadings of their privately managed counterparts. The regression equation is:

$$
\mathrm{R}_{\mathrm{jt}}^{\mathrm{PUB}}-\mathrm{R}_{\mathrm{jt}}^{\mathrm{PRI}}=\alpha_{\mathrm{j}}+\beta_{\mathrm{mj}}\left(\mathrm{R}_{\mathrm{mt}}-\mathrm{R}_{\mathrm{Ft}}\right)+\beta_{\mathrm{sj}} \mathrm{SMB}_{\mathrm{t}}+\beta_{\mathrm{hj}} \mathrm{HML}_{\mathrm{t}}+\epsilon_{\mathrm{jt}}
$$

where $R_{j t}{ }^{P U B}$ is the equally-weighted return of the type $\mathrm{j}$ mutual funds managed by the publicly-traded management companies in $t$ and $\mathrm{R}_{\mathrm{jt}}{ }^{\mathrm{PRI}}$ is the equally-weighted return of the type $\mathrm{j}$ mutual funds managed by the private management companies in $\mathrm{t}$.

A. Dependent variable: The difference in the return of the Canadian equity funds managed by the publiclytraded management companies and private management companies.

\begin{tabular}{|lcc|}
\hline \hline Independent Variables & Estimate & t-statistic \\
\hline Intercept & -0.0017 & -2.13 \\
$\mathrm{R}_{\mathrm{mt}}-\mathrm{R}_{\mathrm{Ft}}$ & -0.0154 & -0.79 \\
$\mathrm{SMB}_{\mathrm{t}}$ & 0.0449 & 1.95 \\
$\mathrm{HML}_{\mathrm{t}}$ & -0.0299 & -1.51 \\
\hline
\end{tabular}

B. Dependent variable: The difference in the return of the Canadian balanced funds managed by the publiclytraded management companies and private management companies.

\begin{tabular}{|lcc|}
\hline \hline Independent Variables & Estimate & t-statistic \\
\hline Intercept & -0.0004 & -0.46 \\
$\mathrm{R}_{\mathrm{mt}}-\mathrm{R}_{\mathrm{Ft}}$ & 0.0615 & 2.99 \\
$\mathrm{SMB}_{\mathrm{t}}$ & 0.0075 & 0.31 \\
$\mathrm{HML}_{\mathrm{t}}$ & -0.0038 & -0.18 \\
\hline
\end{tabular}

C. Dependent variable: The difference in the return of the Canadian equity funds invested in U.S. securities managed by the publicly-traded management companies and private management companies.

\begin{tabular}{|lcc|}
\hline \hline Independent Variables & Estimate & $\mathrm{t}$-statistic \\
\hline Intercept & -0.0001 & -0.08 \\
$\mathrm{R}_{\mathrm{mt}}-\mathrm{R}_{\mathrm{Ft}}$ & 0.0045 & 0.11 \\
$\mathrm{SMB}_{\mathrm{t}}$ & 0.0764 & 1.31 \\
$\mathrm{HML}_{\mathrm{t}}$ & -0.0155 & -0.21 \\
\hline
\end{tabular}


Table 8

\section{Percentage of Funds with Significant Risk Loadings on Three Factors}

This table compares the percentages the funds having significantly positive risk loading at $95 \%$ confident level which are managed by the publicly-traded management companies and private management companies.

\begin{tabular}{lcccccc}
\hline & $\begin{array}{c}\text { Canadian Equity } \\
\text { Funds }(\%)\end{array}$ & \multicolumn{2}{c}{$\begin{array}{c}\text { Canadian Bal. Funds } \\
(\%)\end{array}$} & \multicolumn{2}{c}{$\begin{array}{c}\text { Cdn. Eq. Funds } \\
\text { Invested in U.S. (\%) }\end{array}$} \\
\hline & & & & & & \\
Market Risk & 100.0 & 100.0 & 100.0 & 100.0 & 100.0 & 100.0 \\
Size Risk & 60.5 & 52.4 & 10.1 & 0.0 & 62.6 & 52.9 \\
Book to & 29.9 & 15.5 & 60.0 & 44.4 & 23.1 & 22.4 \\
Market Risk & & & & & & \\
\hline
\end{tabular}




\section{Table 9}

\section{Cross-Sectional Regression for the Determinants for the Management Fee, Administrative Fee and Expense Ratio}

The table reports the cross-sectional regressions for determinants of the management fees, expense ratio and administrative fees of the funds managed by the publicly-traded management companies and private management companies. The expense ratio includes the management fee and administrative fee. The dependent variables, $\mathrm{FEE}_{\mathrm{i}}$, is management fee, administrative fee or expense ratio for fund $\mathrm{i}$. The independent variables are $\log \left(\mathrm{SIZE}_{\mathrm{i}}\right), \log \left(\mathrm{MGTSIZE}_{\mathrm{i}}\right), \mathrm{AGE}_{\mathrm{i}}$, LOAD $_{\mathrm{i}}$, TYPE $_{\mathrm{i}}, \mathrm{MGT}_{\mathrm{i}} \cdot \mathrm{SIZE}_{\mathrm{i}}$ is mutual fund i's total net asset value. MGTSIZE is the size of mutual fund i's management company measured by the number of the mutual funds that the management company manages. $A_{G E}$ is the age of mutual fund $i . L O A D_{i}$ is a dummy variable equal to 1 if the fund $i$ is a load fund and equal to 0 if the fund is a no-load fund. TYPE $E_{\mathrm{i}}$ is a dummy variable equal to 1 if fund $i$ is an equity fund and equal to 0 if the fund is a balanced fund. $\mathrm{MGT}_{\mathrm{i}}$ is a dummy variable and equal to 1 if the fund i's management company is publicly-traded and equal to 0 if the fund's management company is private. The regression equation is:

$$
\text { FEE }_{i}=a+b_{1} \log \left(\text { SIZE }_{i}\right)+b_{2} \log \left(\text { MGTSIZE }_{\mathrm{i}}\right)+\mathrm{b}_{3} \mathrm{AGE}_{\mathrm{i}}+\mathrm{b}_{4} \mathrm{LOAD}_{\mathrm{i}}+\mathrm{b}_{5} \text { TYPE }_{\mathrm{i}}+\mathrm{b}_{6} \mathrm{MGT}_{\mathrm{i}}
$$

A. Dependent variable: Management Fees

\begin{tabular}{|lcc|}
\hline \hline Independent Variables & Coefficient & t-statistic \\
\hline $\log \left(\right.$ SIZE $\left._{\mathrm{i}}\right)$ & -0.0083 & -0.25 \\
$\log \left(\right.$ MGTSIZE $\left._{\mathrm{i}}\right)$ & -0.0564 & -0.35 \\
$\mathrm{AGE}_{\mathrm{i}}$ & 0.0004 & 0.08 \\
$\mathrm{LOAD}_{\mathrm{i}}$ & -0.1959 & -1.42 \\
$\mathrm{TYPE}_{\mathrm{i}}$ & 0.3480 & 2.69 \\
$\mathrm{MGT}_{\mathrm{i}}$ & 0.4940 & 3.72 \\
\hline
\end{tabular}

B. Dependent variable: Expense Fees

\begin{tabular}{|lcc|}
\hline \hline Independent Variables & Coefficient & t-statistic \\
\hline $\log \left(\right.$ SIZE $\left._{\mathrm{i}}\right)$ & -0.0154 & -0.59 \\
$\log \left(\right.$ MGTSIZE $\left._{\mathrm{i}}\right)$ & -0.3458 & -2.81 \\
$\mathrm{AGE}_{\mathrm{i}}$ & -0.0046 & -1.17 \\
$\mathrm{LOAD}_{\mathrm{i}}$ & -0.0345 & -0.33 \\
$\mathrm{TYPE}_{\mathrm{i}}$ & 0.0435 & 0.44 \\
$\mathrm{MGT}_{\mathrm{i}}$ & 0.6153 & 6.02 \\
\hline
\end{tabular}

C. Dependent Variable: Administrative Fees

\begin{tabular}{|lcc|}
\hline Independent Variables & Coefficient & t-statistic \\
\hline $\log \left(\mathrm{SIZE}_{\mathrm{i}}\right)$ & -0.0071 & -0.21 \\
$\log \left(\mathrm{MGTSIZE}_{\mathrm{i}}\right)$ & -0.2894 & -1.84 \\
$\mathrm{AGE}_{\mathrm{i}}$ & -0.0050 & -0.99 \\
$\mathrm{LOAD}_{\mathrm{i}}$ & 0.1613 & 1.19 \\
TYPE $_{\mathrm{i}}$ & -0.3045 & -2.39 \\
$\mathrm{MGT}_{\mathrm{i}}$ & 0.1213 & 0.93 \\
\hline
\end{tabular}


Figure 1a

Mutual Fund Complex

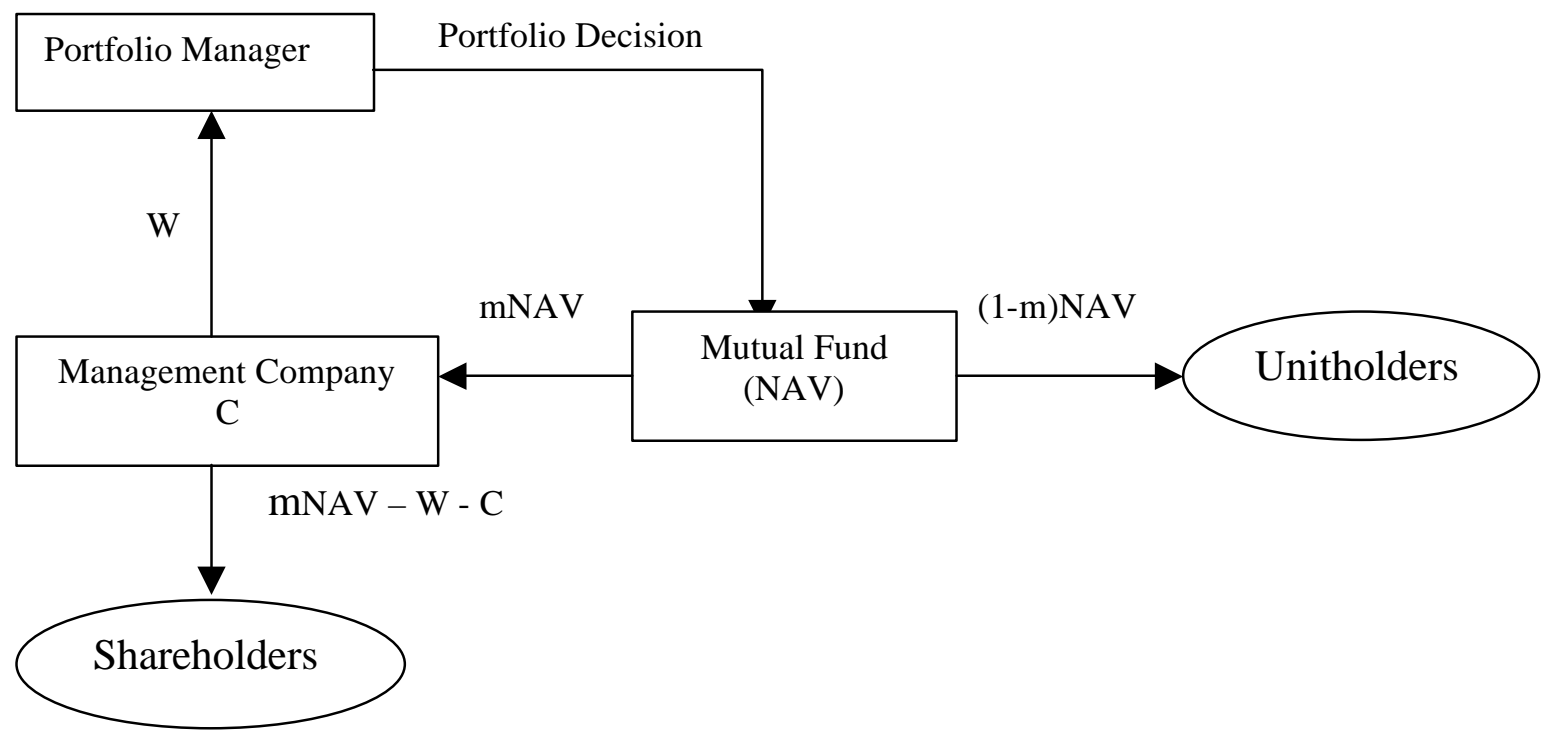

Figure 1b

Corporation

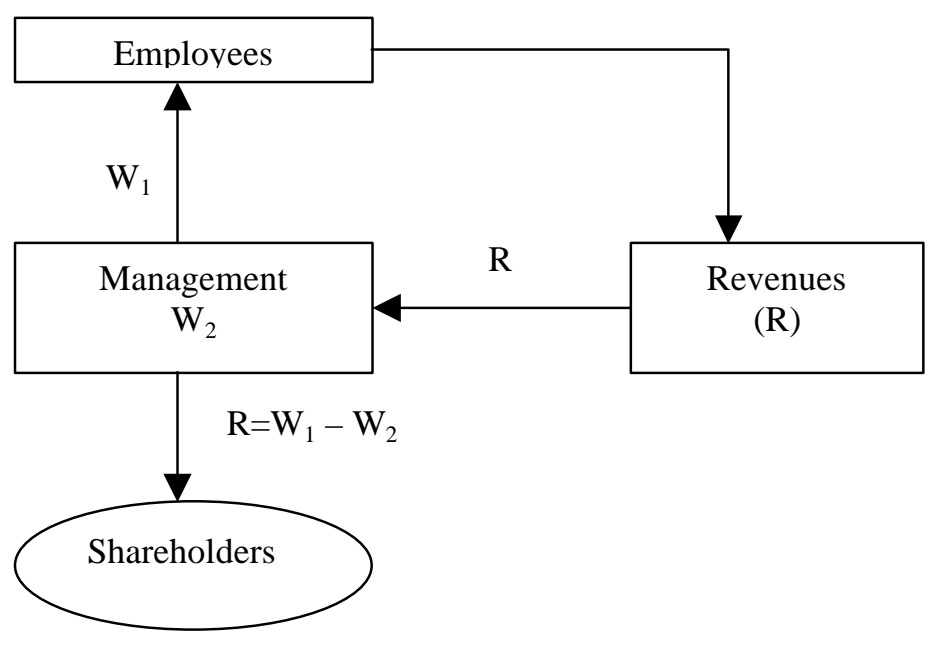

